\title{
Antibiotic resistance profiling of marine halophilic bacteria and haloarchaea
}

\author{
Vinaya D. Shinde, Rebecca S. Thombre* \\ Department of Biotechnology, Modern College of Arts, Science and Commerce, Shivajinagar, Pune-411005. India.
}

\begin{tabular}{|c|c|}
\hline ARTICLE INFO & ABSTRACT \\
\hline $\begin{array}{l}\text { Article history: } \\
\text { Received on: } 11 / 04 / 2016 \\
\text { Revised on: } 09 / 05 / 2016 \\
\text { Accepted on: } 24 / 06 / 2016 \\
\text { Available online: } 29 / 10 / 2016\end{array}$ & $\begin{array}{l}\text { Drug resistance in microorganisms is an emerging phenomenon that poses challenges to public health and } \\
\text { treatment. The reservoir of drug resistance genes found in the resistome of environmental isolates in aquatic } \\
\text { saline systems has been augmenting continuously. The spread of drug resistance is attributed to the } \\
\text { dissemination of drug resistant pathogens occurring in sewage and wastewater released in the marine } \\
\text { environments like seas. Halophiles are salt loving organisms that are found naturally in these marine }\end{array}$ \\
\hline $\begin{array}{l}\text { Key words: } \\
\text { Halophiles, haloarchaea, } \\
\text { marineisolate, antibiotic } \\
\text { resistance, plasmid, efflux } \\
\text { pump, coastal Maharashtra, } \\
\text { environmental } \\
\text { microorganisms. }\end{array}$ & $\begin{array}{l}\text { profile of halophiles isolated from marine ecosystems of the coastal Maharashtra, India using disk diffusion } \\
\text { method. The plausible mechanism of drug resistance in the marine halophiles was investigated by detecting } \\
\text { plasmids and antibiotic efflux pumps using EtBr-Cart wheel assay. The haloarchaea, Haloarcula sp. RR } 14 \text { and } \\
\text { Halovivax sp. RT5 showed multidrug resistance and presence of efflux pumps ( } \mathrm{MIC}_{\mathrm{EtBr}}=0.5 \mu \mathrm{g} / \mathrm{ml} \text { ). The } \\
\text { resistance of gram positive halophiles was in following order: Salimicrobium salexigens } \mathrm{RR} 5>\text { Salimicrobium } \\
\text { flavidum RR } 2 \text { Alkalibacillus almallahensis } \mathrm{RR} 3 \text {. Amongst gram negative halophiles, their resistance was in } \\
\text { following order: Halomonas smyrnensis RR7 > Halomonas koreensis RR } 1>\text { Marinobacter oulmenensis RR6. } \\
\text { Plasmids were detected in Haloarcula sp., Halomonassp. and Marinobacter sp. The present study related to } \\
\text { antibiotic resistance of halophiles from marine environment is significant as some of the marine halophilic } \\
\text { isolates like Halomonas sp. have been reported as potential pathogens in recent times. }\end{array}$ \\
\hline
\end{tabular}

\section{INTRODUCTION}

The emergence of drug resistance has increased in recent times challenging the line of treatment used for diseases. Besides, drug resistance in disease causing bacteria and organisms causing nosocomial infections, the drug resistance has now spread to bacteria present in the environment. A reservoir of drug resistance genes has been accumulating in non-pathogenic environmental microorganisms found in coastal seas, estuarine environments and deep ocean water (Vaidya 2011; Da Costa et al., 2013). The spread of drug resistance is attributed to the release of non-disinfected wastewaters including sewage and

\footnotetext{
* Corresponding Author

Rebecca S Thombre, Dept. of Biotechnology, Modern College of Arts, Science and Commerce, Shivajinagar,Pune-411005. India mail id:rebecca.thombre@gmail.com
}

waste water from hospitals into the marine/aquatic environment (Da Costa et al., 2013). A study conducted in Mumbai, India reported the spread of antibiotic resistant Escherichia coli, Klebsiella pneumoniae, Pseudomonas and Salmonella paratyphi B in the coastal sea waters of Mumbai (Ali and Vaidya., 2008). Similarly, a recent study reported the spread of antibacterial resistant bacteria especially Extended Spectrum $\beta$-lactamase (ESBL) producing strains in 22 rivers of America (Vaidya 2011). The dissemination of the antibiotic resistance genes from pathogens to the environmental isolates occurs via horizontal gene transfer by conjugal transfer of plasmids. There are many factors associated with the acquisition of drug resistance by environmental isolates like use and abuse of drugs, increased multi drug resistant bacteria in aquatic habitats and transfer of antibiotic resistance plasmids by conjugation or transformation. Halophilic organisms form a major portion of the microbial community that inhabits sea water (Ventosa et al., 1998). 
Halophilic organisms are salt loving organism found in the prokaryotic as well as eukaryotic kingdom. Halophiles are classified as slight $(2-5 \% \mathrm{NaCl})$, moderate $(5-20 \% \mathrm{NaCl})$ or extreme halophiles $\left(\begin{array}{llll}20 & -30 & \% & \mathrm{NaCl}\end{array}\right)$ depending on their requirement for $\mathrm{NaCl}$ (Oren 2008). Halophiles comprise a heterogeneous group of heterotrophic, methanogenic and photosynthetic archaea, bacteria and eukaryotes (DasSarma et al., 2010). Oren et al. (2009) have described the emended details of Halobacteriaceae family and till date the family comprises of 36 genera and 129 species (Oren et al., 1997, 2009). Halophiles are found in aquatic systems, salterns, salt lakes, marshes and have been isolated from low salinity environments like sea water (Thombre and Oke. 2015) and hypersaline environments like saltern brines (Digaskar et al., 2014). The metabolites produced by halophiles like ectoine, betaine, carotenoid pigments, enzymes, anticancer and antibacterial compounds have immense applications in pharmacy and biomedicine (Thombre et al., 2016).

The occurrence of drug resistance in bacterial inhabitants of sea water and oceans is increasing because of the horizontal gene transfer of antibiotic resistant genes from pathogens that are disseminated in the sea via release of sewage in sea (Da Costa et $a l ., 2013)$. Sea water and aquatic systems are the natural ecological habitat of halophiles. Hence in the present investigation, halophiles previously isolated from sea water of the Arabian sea, lining the Sindhudurg district in coastal Maharashtra, India were screened for the occurrence of antibiotic resistance characteristics.

Halophiles are a group of gram positive and negative bacteria belonging to different genera like Vibrio, Micrococcus, Salimicrobium, Halomonas, Marinococcus, Flavobacterium and Planococcus (Ventosa et al., 1998). Some halophiles like Vibrio (Yamazi et al., 1959) and Halomonas(Stevens et al., 2009) are known pathogens while the pathogenicity of other halophiles and haloarchaea is largely unknown (Ventosa et al., 1998; Stevens et al., 2009). As the pathogenic nature of some halophiles is reported, the study related to antibiotic resistance of halophiles from marine aquatic environment is important.

The aim of the present report was to investigate the antibiotic resistance profile of marine halophiles, to detect the presence of plasmids and to study the possible mechanism of resistance by assessing the presence of antibiotic efflux pumps.

\section{MATERIALS AND METHODS}

\section{Microbial strains and culture conditions}

The halophilic bacteria and archaea were isolated in the laboratory using enrichment culture technique from marine samples collected from West Coast of Maharashtra, India as described previously (Thombre and Oke, 2015, Digaskar et al., 2014).The medium used for growth of the halophilic bacteria and archaea was Sehgal and Gibbons (SG) medium supplemented with $15 \% \mathrm{NaCl}$. The components of the medium included $(\mathrm{g} / 100 \mathrm{ml})$ : casamino acids- 0.75 , yeast extract- $1, \mathrm{KCl}-0.2$, trisodium citrate0.3, $\mathrm{MgSO}_{4^{-}}$2, NaCl- 15, pH: 7.2 (Sehgal and Gibbons, 1960). The incubation conditions for halophilic bacteria was $30-37^{\circ} \mathrm{C}$ for
7- 15 days and for haloarchaea was $40{ }^{\circ} \mathrm{C}$ for 5-7 days. The halophiles used in the study are enlisted in Table 1 .The cultures were preserved as glycerol stocks at $-20^{\circ} \mathrm{C}$.

Table 1: Halophilic strains isolated from marine habitat of West Coast of India used for in the study.

\begin{tabular}{llcc}
\hline No. & Name & $\begin{array}{c}\text { Strain } \\
\text { designation }\end{array}$ & $\begin{array}{c}\text { NCBI GenBank } \\
\text { Accession Number }\end{array}$ \\
\hline 1 & Halomonas koreensis & RR1 & KP712892 \\
2 & Salimicrobium flavidum & RR2 & KP739939 \\
3 & Alkalibacillus almallahensis & RR3 & KP739944 \\
4 & Salimicrobium salexigens & RR5 & KP739943 \\
5 & Marinobacteroulmenensis & RR6 & KP739941 \\
6 & Halomonas smyrnensis & RR7 & KP739942 \\
7 & Haloarcula sp. & RR14 & KP712895 \\
8 & Halovivax sp. & RT5 & KP712882 \\
\hline
\end{tabular}

\section{Antibiotic resistance profiling of marine halophiles}

The antibiotic sensitivity test was performed by the disk diffusion method according to the Clinical and Laboratory Standards Institute (CLSI) guidelines (2012) with slight modifications in terms of medium used. The medium used for the halophilic bacteria and haloarchaea was Sehgal and Gibbons (SG) medium containing $15 \% \mathrm{NaCl}$ (Himedia, India)instead of the standard Mueller -Hinton Agar (MHA) (Himedia, India) as MHA did not support the growth of extreme halophiles and haloarchaea. The inoculum was prepared as per the CLSI guidelines (2012). Briefly, the turbidity of the exponential phase culture was adjusted to match the turbidity of $0.5 \mathrm{Mc}$ Farland standard which corresponds to $10^{8}$ cells $/ \mathrm{ml}$. The incubation temperature was 37$40{ }^{\circ} \mathrm{C}$ for 5-7 days or till growth appeared. The antibiotics used were Augmentin, Norfloxacin, Nalidixic acid, Imipenem, Tobramycin, Cefoxitin, Cefoperazone and Piperacillin/Tazobactam (HiMedia, India). Presently there are no standard guidelines and interpretive criteria mentioned by CLSI for halophilic bacteria and archaea. Hence for interpreting the results of antibacterial sensitivity testing of the gram positive halophilic bacterial isolates (Salimicrobium flavidumRR2, Salimicrobium salexigensRR5 and Alkalibacillus almallahensis RR3)the interpretive criteria and breakpoints suggested by CLSI (2014) for gram positive Staphylococcus aureus was used. Similarly, for gram negative halophiles and haloarchaea (Halomonas koreensis RR1, Marinobacter oulmenensis RR6, Halomonas smyrnensis RR7, Haloarcula sp. and Halovivax sp.)the interpretive criteria and breakpoints suggested by CLSI (2014) for gram negative Escherichia coli was used. For some antibiotics (Novobiocin, Bacitracin) the interpretive criteria were not mentioned in CLSI (2014) supplementand these were interpreted as resistant or sensitive as per guidelines for halophilic archaea described by Oren et al., 1997, 2009.

\section{Extraction of plasmid DNA from halophilic bacteria and archaea}

The extraction of plasmid from halophilic bacteria was performed as described by Argandon et al., 2003. Briefly, the cell pellet of haloarchaea was suspended in $50 \mu \mathrm{l}$ of $1 \mathrm{M} \mathrm{NaCl}$ 
(Himedia, India) and lysed with $200 \mu \mathrm{l}$ SDS/OH solution $(1 \% / 0.2 \mathrm{M})$. After mixing gently for $10 \mathrm{~min}$, the solution was treated with $150 \mu \mathrm{l}$ potassium acetate and mixed by inversion and centrifuged at 10,000 rpm for 5 min using a refrigerated centrifuge (C-24 Remi, India). The supernatant was precipitated with two volumes of chilled ethanol, the plasmid is obtained after centrifugation and visualized by agarose gel electrophoresis as described by Argandon et al., 2003.

\section{Antibiotic efflux pump assay}

The antibiotic resistance efflux pumps produced in halophilic bacteria and haloarchaea were detected by modification of Ethidium Bromide- agar Cartwheel method (Martins et al., 2011). Briefly, the saline suspension of the halophiles (Absorbance adjusted to 0.5 of Mc Farland standard) were streaked on SG agar with $15 \% \mathrm{NaCl}$ supplemented with $\mathrm{EtBr}$ (Sisco Research Laboratories, India)( 0 to $\left.2.5 \mathrm{mg} \mathrm{L}^{-1}\right)$ divided into radial sectors and incubated at $37-40^{\circ} \mathrm{C}$ for 5-7 days till growth appeared. The plates were examined under UV transilluminator and the minimum concentration of $\mathrm{EtBr}\left(\mathrm{MIC}_{\mathrm{EtBr}}\right)$ that produced fluorescence was recorded. The experiment was performed in triplicates.

\section{RESULTS AND DISCUSSION}

Halophiles are extremely resistant to different stresses like perchlorate, temperature and salinity (Chitnis and Thombre, 2014). The natural and acquired resistance to antibiotics in halophiles is also an intriguing feature of paramount importance. With the rising occurrence of drug resistance in bacteria at alarming rates, the treatment strategies and containment of the multi drug resistant strains (MDR) poses a great challenge. The drug resistance in microorganism is attributed to many factor. The ability to produce enzymes like $\beta$-lactamases, alterations of cell wall permeability and chromosomal mutations and activation of efflux pumps are few of the mechanism of drug resistance (Mapara et al., 2015). The most common mechanism by which bacteria acquire drug resistance is plasmids. Dealing with plasmid mediated resistance is more difficult as the antibiotic resistance genes can be easily transferred between different populations leading to release of the drug resistant genes in environmental population. Besides plasmid, the presence of antibiotic efflux pumps is also a common strategy adapted my microorganisms to garner resistance to antibiotic drugs. The present investigation focused on profiling the antibiotic resistance in halophiles and exploring for the presence of plasmids and efflux pumps in them. The halophilic isolates from marine ecosystems were profiled for their antibiotic resistance and the results are summarized in table 2 .

As observed from Table 2, all the halophilic bacteria and haloarchaea were resistant to ampicillin, ciprofloxacin, bacitracin and chloramphenicol. The haloarchaea were resistant to all the antibiotics. Though there are no standard CLSI guidelines for the classification of drug resistance in haloarchaea, as the standard definition of multidrug resistance is the ability to be resistant to minimum one drug in more than three classes of antibiotics, the haloarchaea investigated in the present study can be considered to be multidrug resistant strains. However, the classification of drug resistance due to the variations in cell wall and inherent mechanisms of drug resistance in haloarchaea is still a subject of contemplation. The marine halophiles also showed marked resistance to antibiotics. Salimicrobium sp. and Alkalibacillus almallahensis were resistant to many antibiotics like ampicillin, streptomycin, bacitracin, ciprofloxacin and tetracycline (Table 2).Halomonas sp. was resistant to ampicillin, streptomycin, bacitracin, ciprofloxacin, tetracycline, erythromycin, chloramphenicol and gentamicin (Table 3). Similar antibiotic resistance was observed in gram negative halophile Marinobacter oulmenensis. Most halobacteria are sensitive to bacitracin and resistant to penicillins, cycloserine, kanamycin and neomycin (Ghosh et al., 2010). The haloarchaea, Haloarcula sp. RR14 and Halovivax sp. RT5 were resistant to almost all antibiotics. The antibiotic resistance was in the following order:Haloarchaea (RT5, RR15) > Halomonas sp. >Marinobacter sp. > Salimicrobium sp. $>$ Alkalibacillus sp.

Table 2: Antibiotic resistance profile of gram positive marine halophilic bacteria by disk diffusion method. [Legend: R-resistant, I - Intermediate, S- Sensitive; Interpretive criteria of *Staphlococcus aureus; ${ }^{*}$ Enterococci as per guidelines of CLSI M100-S24 for disk diffusion. Isolates:Salimicrobium flavidumRR2, Alkalibacillus almallahensis RR3, Salimicrobium salexigensRR5].

\begin{tabular}{|c|c|c|c|c|c|c|c|c|}
\hline \multirow[t]{2}{*}{ Name of antibiotic } & \multirow{2}{*}{$\begin{array}{l}\text { Concentration } \\
(\mu \mathrm{g} / \mathrm{ml})\end{array}$} & \multirow[t]{2}{*}{ Class } & \multicolumn{3}{|c|}{$\begin{array}{l}\text { Interpretive Criteria for Zone } \\
\text { Diameter }^{*}(\mathrm{~mm})\end{array}$} & \multicolumn{3}{|c|}{$\begin{array}{l}\text { Antibiotic resistance profile of } \\
\text { marine halophilic isolates }\end{array}$} \\
\hline & & & $\mathbf{S}$ & I & $\mathbf{R}$ & RR2 & RR3 & RR5 \\
\hline Ampicillin & 10 & $\beta$-Lactam & $\geq 17$ & - & $<16$ & $\mathrm{R}$ & $\mathrm{R}$ & $\mathrm{R}$ \\
\hline Streptomycin & 25 & Aminoglycoside & $\geq 10$ & $7-9$ & $\leq 6$ & $\mathrm{R}$ & $\mathrm{S}$ & $\mathrm{R}$ \\
\hline Bacitracin & 10 & Polypeptide & - & - & - & $\mathrm{R}$ & $\mathrm{R}$ & $\mathrm{R}$ \\
\hline Novobiocin & 30 & Aminocoumarin & - & - & - & $\mathrm{R}$ & $\mathrm{S}$ & $\mathrm{R}$ \\
\hline Ciprofloxacin & 5 & Fluoroquinolone & $\geq 21$ & $16-20$ & $\leq 15$ & $\mathrm{R}$ & $\mathrm{R}$ & $\mathrm{R}$ \\
\hline Tetracycline & 30 & Tetracycline & $\geq 19$ & $15-18$ & $\leq 14$ & $\mathrm{R}$ & $\mathrm{R}$ & $\mathrm{R}$ \\
\hline Erythromycin\# & 15 & Macrolides & $\geq 23$ & $14-22$ & $\leq 13$ & $\mathrm{~S}$ & $\mathrm{~S}$ & $\mathrm{R}$ \\
\hline Chloramphenicol & 30 & Phenicol & $\geq 18$ & $13-17$ & $\leq 12$ & $\mathrm{R}$ & $\mathrm{R}$ & $\mathrm{R}$ \\
\hline Trimethoprim & 25 & Folate pathway inhibitor & $\geq 16$ & $11-15$ & $\leq 10$ & $\mathrm{R}$ & $\mathrm{S}$ & $\mathrm{R}$ \\
\hline Gentamicin & 10 & Aminoglycoside & $\geq 15$ & $13-14$ & $\leq 12$ & $\mathrm{~S}$ & $\mathrm{~S}$ & $\mathrm{~S}$ \\
\hline
\end{tabular}


Table 3: Antibiotic resistance profile of gram negative marine halophilic bacteria and haloarchaea by disk diffusion method. [Legend: R-resistant, I Intermediate, S- Sensitive; Interpretive criteria of* Enterobacteracieae $\left\{\right.$ E. coli\}; ${ }^{\sharp}$ Enterococci as per guidelines of CLSI M100-S24 for disk diffusion. Isolates: Halomonas koreensis RR1, Marinobacteroulmenensis RR6, Halomonas smyrnensis RR7, Haloarcula sp.RR14, and Halovivax sp.RT5].

\begin{tabular}{|c|c|c|c|c|c|c|c|c|c|c|}
\hline \multirow[t]{2}{*}{ Name of antibiotic } & \multirow{2}{*}{$\begin{array}{c}\text { Concentration } \\
(\mu \mathrm{g} / \mathrm{ml})\end{array}$} & \multirow[t]{2}{*}{ Class } & \multicolumn{3}{|c|}{$\begin{array}{l}\text { Interpretive Criteria for } \\
\text { Zone Diameter* }(\mathrm{mm})\end{array}$} & \multicolumn{5}{|c|}{$\begin{array}{l}\text { Antibiotic resistance profile of marine halophilic } \\
\text { isolates }\end{array}$} \\
\hline & & & $\mathbf{S}$ & I & $\mathbf{R}$ & RR1 & RR6 & RR7 & RR14 & RT5 \\
\hline Ampicillin & 10 & $\beta$-Lactam & $\geq 17$ & $14-16$ & $\leq 13$ & $\mathrm{R}$ & $\mathrm{R}$ & $\mathrm{R}$ & $\mathrm{R}$ & $\mathrm{R}$ \\
\hline Streptomycin & 25 & Aminoglycoside & $\geq 15$ & $12-14$ & $\leq 11$ & $\mathrm{R}$ & $\mathrm{R}$ & $\mathrm{R}$ & $\mathrm{R}$ & $\mathrm{R}$ \\
\hline Bacitracin & 10 & Polypeptide & - & - & - & $\mathrm{R}$ & $\mathrm{R}$ & $\mathrm{R}$ & $\mathrm{R}$ & $\mathrm{R}$ \\
\hline Novobiocin & 30 & Aminocoumarin & - & - & - & $\mathrm{S}$ & $\mathrm{S}$ & $\mathrm{R}$ & $\mathrm{R}$ & $\mathrm{R}$ \\
\hline Ciprofloxacin & 5 & Fluoroquinolone & $\geq 21$ & $16-20$ & $\leq 15$ & $\mathrm{R}$ & $\mathrm{R}$ & $\mathrm{R}$ & $\mathrm{R}$ & $\mathrm{R}$ \\
\hline Tetracycline & 30 & Tetracycline & $\geq 15$ & $12-14$ & $\leq 11$ & $\mathrm{R}$ & $\mathrm{R}$ & $\mathrm{R}$ & $\mathrm{R}$ & $\mathrm{R}$ \\
\hline Erythromycin & 15 & Macrolides & $\geq 23$ & $14-22$ & $\leq 13$ & $\mathrm{R}$ & S & $\mathrm{R}$ & $\mathrm{R}$ & $\mathrm{R}$ \\
\hline Chloramphenicol & 30 & Phenicol & $\geq 18$ & $13-17$ & $\leq 12$ & $\mathrm{R}$ & $\mathrm{R}$ & $\mathrm{R}$ & $\mathrm{R}$ & $\mathrm{R}$ \\
\hline Trimethoprim & 25 & Folate pathway inhibitor & $\geq 16$ & $11-15$ & $\leq 10$ & $\mathrm{~S}$ & $\mathrm{R}$ & $\mathrm{S}$ & $\mathrm{R}$ & $\mathrm{R}$ \\
\hline Gentamicin & 10 & Aminoglycoside & $\geq 15$ & $13-14$ & $\leq 12$ & $\mathrm{R}$ & $\mathrm{R}$ & $\mathrm{R}$ & $\mathrm{R}$ & $\mathrm{R}$ \\
\hline
\end{tabular}
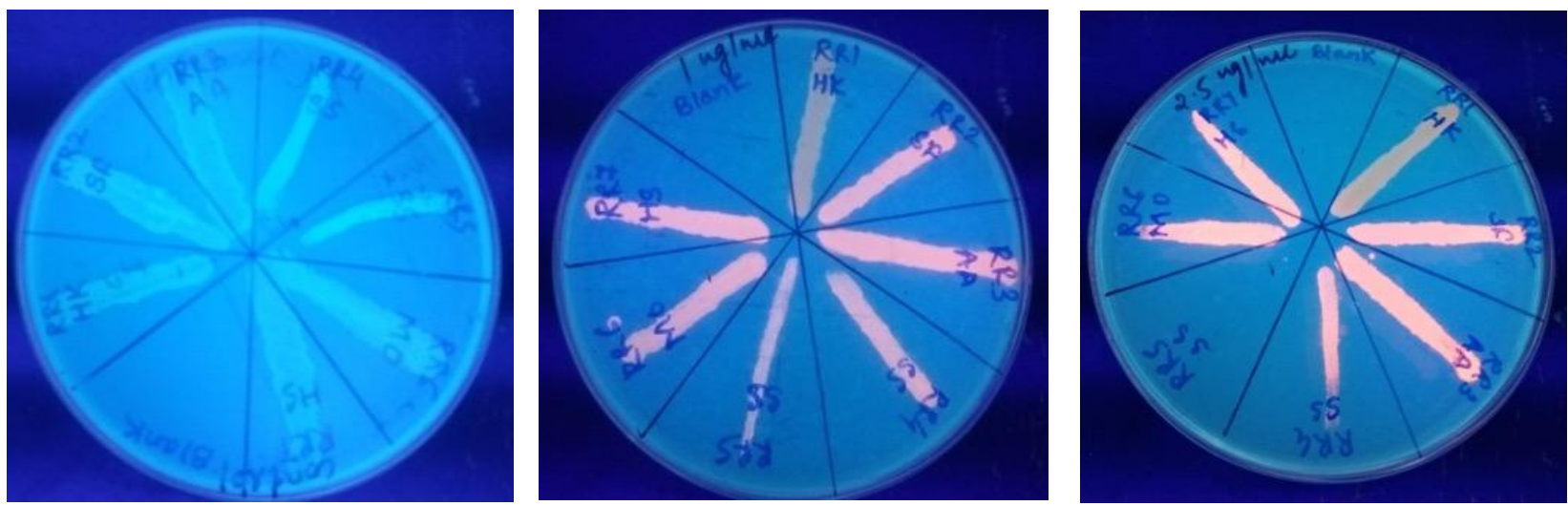

Fig 1: Detection of antibiotic efflux pump in halophiles by Ethidium Bromide Cart-Wheel Assay. (Plate 1: Control, Plate 2: SG with $1 \mu \mathrm{g} / \mathrm{ml}$ EtBr, Plate 3: SG medium with $2.5 \mu \mathrm{g} / \mathrm{mlEtBr}$ ).

The acquisition of drug resistance is generally by natural genetic transformation as a mechanism of horizontal transfer of drug resistance genes (Vaidya 2011). The bacteria can acquire the genes either by transformation by uptake of naked DNA from the environment pool or by transfer of plasmids by conjugation. In either case, the transfer of genes from the pathogens released in natural econiches to environmental isolates is inevitable (Vaidya 2011). The presence of plasmids is commonly associated with antimicrobial resistance in bacteria and most of these extrachromosomal replicons harbor drug resistance genes. Plasmids and mega plasmids have been reported in halophiles earlier (Montserrat et al., 2003). The presence of plasmids has previously been reported in halophiles isolates from tannery waste (Ghosh et al., 2010).The presence of plasmids that may be the plausible underlying mechanism of drug resistance in these marine isolates was studied and the results are shown in Table 4.Plasmids were detected in Haloarcula sp., Halomonas sp. and Marinobactersp. demonstrating that drug resistance may be plasmid encoded in these isolates. As Halomonas sp. is a known pathogen, the detection of plasmid in this drug resistant marine isolate is a significant finding. Amongst the other mechanisms of drug resistance is the overproduction of antibiotic efflux pumps.
The detection of efflux pumps by Ethidium bromide Cart-wheel assay is depicted in Table 4 and Fig. 1. Efflux pumps are membrane proteins found in gram positive and negative bacteria that have the ability of extrusion of antibiotics from within the cells. Presence of efflux pump is often linked to antimicrobial resistance in bacteria (Martins et al., 2011).

Table 4: Presence of antibiotic efflux pumps and plasmid in halophilic isolates.

\begin{tabular}{llccc}
\hline $\begin{array}{c}\text { Isolate } \\
\text { no }\end{array}$ & $\begin{array}{c}\text { Name of halophilic marine } \\
\text { bacteria and haloarchaea }\end{array}$ & $\begin{array}{c}\text { Presence of } \\
\text { antibiotic } \\
\text { efflux pump }\end{array}$ & $\begin{array}{c}\text { MIC } \\
\mathbf{E t B r} \\
\boldsymbol{\mu g} / \mathbf{m l}\end{array}$ & $\begin{array}{c}\text { Presence } \\
\text { of plasmid } \\
\text { DNA }\end{array}$ \\
\hline RR1 & Halomonas koreensis & - & 0 & + \\
RR2 & Salimicrobium flavidum & + & 1 & - \\
RR3 & Alkalibacillus almallahensis & + & 1 & - \\
RR4 & Salimicriobiumsalexigens & + & 1 & - \\
RR5 & Salimicriobiumsalexigens & + & 1 & - \\
RR6 & Marinobacter oulmenensis & + & 1 & + \\
RR7 & Halomonas smyrnensis & + & 1 & + \\
RR14 & Haloarcula sp. & + & 0.5 & + \\
RT5 & Halovivax sp. & + & 0.5 & - \\
\hline
\end{tabular}

There are five known major categories of efflux pumps: ABC (ATP binding cassettes) transporters, MATE (Multidrug and toxic efflux) pumps, MF (Major facilitator) pumps, SMR (Small Multidrug Resistance) pumps and RND (Root Nodulation and Division) pump(Webber and Piddock, 2002). Halophiles may 
contain any of these pumps and multidrug resistant strains are known to overexpress these efflux pumps. It was observed that most halophiles had the presence of antibiotic efflux pumps which is a significant finding as over expression of efflux transporters is associated with multidrug resistance in bacteria.

The rising menace of MDR strains has instigated researchers to shift focus on the search for natural methods for treating drug resistance. For combating resistance in bacteria, alternative approaches like application of plant extracts, seed extracts and nanoparticles is being explored (Awallelu et al., 2013, Thombre et al., 2013, Francis et al., 2014).

Novel potential phyto-therapeutic agents against multiple drug resistant bacterial strains like plant based extracts have been studied for their potential application in reversal plasmidmediated-resistance (Kumar et al., 2013). Drug resistance is now not restricted to pathogens but has now wide spread occurrence in environmental organisms.Environmental microorganisms are considered to play an active role in biodegradation, bioremediation, bio-geo chemical cycles and production of metabolites. Theincreasing occurrence of antibiotic resistance or MDR strains in environmental microorganism needs to be explored to unravel the probable reasons of natural and acquired drug resistance in them.

In the current investigation, the occurrence of antibiotic resistance in halophiles from marine environment were studied.It was found that these marine isolates were resistant to a variety of antibiotic and most of the isolates showed presence of plasmids and efflux pumps. This highlights the potential role of these organisms as reservoirs of drug resistant genes and increasing augmentation of resistome in the environmental microbiome.

\section{CONCLUSION}

It can be concluded from the present results that the halophilic bacteria and archaea from marine ecosystems were extremely resistant to a wide spectrum of antibiotics. Plasmids were detected in few marine halophilic isolates. The antibiotic resistance may be due to the presence of R-plasmids. Antibiotic efflux pumps were also detected in the marine isolates. The study indicates that the occurrence of antibiotic resistance and multi drug resistance is not limited to only pathogenic bacteria or organisms involved in hospital acquired infections but is also wide spread in marine halophilic bacteria isolated from their natural environment.

\section{ACKNOWLEDGEMENTS}

Authors thank the Principal, Modern College, Pune-5 for providing the facilities to carry out the project work. We are grateful to Dr. Kanekar P.P. for providing standard antibiotic disks.

Financial support and sponsorship: We thank Indian Space Research Organization-Space Technology Cell (ISRO-STC) for providing the financial assistance for the project.
Conflict of Interests: There are no conflicts of interest.

\section{REFERENCES}

Ali MM, Vaidya VK. Antibiotic resistance in pathogens isolated from the coastal marine environment of Mumbai. Bionano Frontier, 2008; $2: 115-23$.

Awallelu K, Thombre R, and Borate A. Antibacterial activity ofCrossandrainfundibuliformis and Jasminumsambac against cell phone bacteria. Cent Euro J Exp Bio, 2013; 2 (1):7-11.

Chitnis A, Thombre R. Study of stress proteins induced by perchlorate and temperature stress in extremely halophilic archaea. Journal of Protein and Proteomics, 2014; 5: 49-50.

Clinical Laboratory Standards Institute. 2012. Performance standards for antimicrobial disc susceptibility tests, Twenty second Informational supplement, Tech. Rep. M100-S22, CLSI. Wayne, Pa, USA, 32: $50-60$.

Clinical Laboratory Standards Institute. 2014. Performance standards for antimicrobial disc susceptibility tests, Twenty fourth Informational supplement, Tech. Rep. M100-S24, CLSI. Wayne, Pa, USA, 34: $1-230$.

Da Costa PM, Loureiro L, Matos AJF. Transfer of MultidrugResistant Bacteria between Intermingled Ecological Niches: The Interface between Humans, Animals and the Environment. International Journal of Environmental Research and Public Health. 2013;10(1):278-294. doi:10.3390/ijerph10010278.

DasSarma P, Coker JA, Huse V, DasSarma S. 2010. Halophiles, industrial applications. In FlickingerMC, ed, Encyclopedia of Industrial Biotechnology. New York: John Wiley,1-9.

Digaskar V, Thombre R and Oke R. 2015. Screening of extremely halophilic archaea for its biotechnological potential. Int J Pharm BioSci,2015; 6:811-819.

Francis G, Thombre R, Parekh F and Lekshminarayan P. Bioinspired Synthesis of Gold Nanoparticles Using FicusBenghalensis (Indian Banyan) leaf extract. ChemSciTrans, 2014; 3(1):470-474.

Ghosh R, Pijush C, Baudhhadeb C, DebasishP. Antibiotic resistance profile of halophilic microorganisms isolated from tannery effluent. IndJBiotech, 2010;9 (1): 80-86.

Kumar V, Shriram V and Mulla J. Antibiotic resistance reversal of multiple drug resistant bacteria using Piper longum fruit extract. J App Pharm Sci. 2013; 3 (03): 112-116.

Mapara N, Sharma M, Shriram V, Bharadwaj R, Mohite KC, Kumar V. Antimicrobial potentials of Helicteresisorasilver nanoparticles against extensively drug-resistant (XDR) clinical isolates of Pseudomonas aeruginosa. ApplMicrobiolBiotechnol, 2015; doi 10.1007/s00253-0156938-x.

Martins M, Viveiros M, Couto I, Costa SS, Pacheco T, Fanning S. Identification of efflux pump-mediated multidrug-resistant bacteria by the Ethidium bromide-agar Cartwheel method. In vivo, 2011; 25: $171-178$.

Montserrat A, Fernando M, Inmaculada L, Emilia Q, Ana M. Megaplasmids in Gram-negative, moderately halophilic bacteria. FEMS Microbiol Lett,2003; 81-86.

Oren A, Ventosa A, Grant WD. Proposed minimal standards for description of new taxa in the order Halobacteriales. Int $\mathrm{J}$ SystBacteriol,1997; 47: 233-238.

Oren A. Microbial life at high salt concentrations: phylogenetic and metabolic diversity Saline Systems, 2008; 4:2 doi:10.1186/17461448-4-2.

Oren A, Arahal DR and Ventosa A. Emended descriptions of genera of the family Halobacteriaaceae. Int J SystEvolMicro, 2009; 59:637-642. doi 10.1099/ijs0.008904-0

Sehgal SN, Gibbons NE. Effect of some metal ions on the growth of Halobacteriumcutirubrum. Can J Microbiol,1960,6:165-169.

Stevens DA, Hamilton JR, Johnson N, Kim KK, Lee JS. Halomonas, a newly recognized human pathogen causing infections and contamination in a dialysis center: three new species. Medicine (Baltimore), 2009; 88 (4): 244-249.doi: 10.1097/MD.0b013e3181aede29. 
Thombre R, JagtapR,Patil N. Evaluation of phytoconstituents, antibacterial, antioxidant and cytotoxic activity of Vitexnegundo and Tabernaemontanadivartica L. Int J Pharm Bio Sci, 2013; 4(1): 389 - 396.

Thombre R and Oke R. Study of stress proteins induced by temperature stress in extremely halophilic archaea, Haloferax mediterrane $i$ RT18. Int J CurrMicrobiol AppSci,2015;2:199-209.

Thombre R, Joshi V, Oke R,2016. Halophiles: Pharmaceutical potential and Biotechnological applications. In: Thangadurai D and Jeyabalan S, ed.Industrial Biotechnology: Sustainable Production and Bioresource Utilization.New Jersey, USA: Apple Academic Press Inc.111139.

Vaidya VK. Horizontal Transfer of Antimicrobial Resistance by Extended-Spectrum $\beta$ Lactamase-Producing Enterobacteriaceae. Journal of Laboratory Physicians, 2011; 3(1), 37-42. http://doi.org/10.4103/09742727.78563.
Webber MA, Piddock LV. The importance of efflux pumps in bacterial antibiotic resistance. J AntimicrobChemother, 2003; 51 (1): 9-11.

Ventosa A. Nieto JJ and Oren A. Biology of Moderately Halophilic Aerobic Bacteria. Microbiology and Molecular Biology Reviews, 1998; 62(2), 504-544.

Yamazi Y, Tsuneo K, Tsuyoshi S, Tiuichi I. Studies on pathogenic halophiles II. Salt requirement for growth and survival, Japan J Microb, 1959; 3(1): 576.

\section{How to cite this article:}

Shinde VD, Thombre RS. Antibiotic resistance profiling of marine halophilic bacteria and haloarchaea. J App Pharm Sci, 2016; 6 (10): 132-137. 